\title{
A Literature Review on Corporate Financialization
}

\author{
Chenrui Wang \\ Department of Accounting, Jinan University, Guangzhou, China \\ Email: 18669608559@163.com
}

How to cite this paper: Wang, C.R. (2019) A Literature Review on Corporate Financialization. American Journal of Industrial and Business Management, 9, 647-657. https://doi.org/10.4236/ajibm.2019.93044

Received: February 19, 2019

Accepted: March 19, 2019

Published: March 22, 2019

Copyright $\odot 2019$ by author(s) and Scientific Research Publishing Inc. This work is licensed under the Creative Commons Attribution International License (CC BY 4.0).

http://creativecommons.org/licenses/by/4.0/

\begin{abstract}
Corporate Financialization is an important and basic branch of economic financialization research, and it is a microscopic manifestation of the economic shift "from real to virtual". Since the 1990s, it has gradually become a hot topic in academic research. By reviewing the classic and cutting-edge literatures on corporate financialization both at home and abroad, this paper summarizes the connotation, measurement and identification, causes and economic consequences of corporate financialization, which helps researchers to further understand corporate financialization from a micro perspective. As well as describing the findings of corporate financialization studies, we highlight some limitations of the literatures and discuss some opportunities for future study.
\end{abstract}

\section{Keywords}

Corporate Financialization, From Real to Virtual, Financialization Degree

\section{Introduction}

Since the 1980s, the international economy has gradually shown a tendency toward financialization. In particular, after the US subprime mortgage crisis in 2008, the excessive development of the virtual economy caused by financialization was blamed as one of the important causes of the crisis, which triggered the extensive discussion and prompted a significant increase in research on financialization. As an important manifestation of the micro level of economic financialization, the phenomenon of financialization of non-financial companies (NFCs) has become increasingly serious. China is in the period of economic transition, and traditional industries are facing the problems of low technology level, single profit model and overcapacity, which make the development of real enterprises, especially traditional enterprises, difficult. Therefore, many NFCs 
have found its way into the financial markets. By arranging financial assets to obtain higher returns and improve profitability, NFCs have gradually deviated from their main business. Thus, corporate funds have vacated from the real economy to the virtual economy, causing the problem of economic shift-"from real to virtual".

Facing financialization, American companies have launched a "deleveraging" campaign, and the Obama administration also mentioned the "re-industrialization" of the US economy. The Chinese government is also highly vigilant about this, and has issued a number of concerning documents to regulate the use of corporate funds. In the report at the 19th National Congress of the Communist Party of China, President Xi Jinping emphasized that the focus of economic development should be placed on the real economy. In this context, studying the causes and economic consequences of corporate financialization has important fundamental significance for taking effective measures to prevent excessive corporate financialization and excessive virtualization.

Compared with the existing literature review, this paper has the following two contributions: 1) Different from the macro perspective of Zhang Chengsi and Zhang Buzhen (2015) [1], Zou Yang (2018) [2], this paper mainly reviews the literature on micro-level; 2) Existing research mainly focused on the causes of financialization and the economic consequences, emphasizing that the different motivations will have different influences, then targeted measures and policies should be taken. But in fact, it is difficult to identify or regulate the real financial motives of NFCs. Based on the extant literature, this paper further proposes that there must be an optimal degree of corporate financialization, and the consequences vary depending upon different financialization degree. We should pay more attention to the economic consequences of excessive financialization.

The rest of the paper is arranged as follows: Section 2 describes prior theoretical studies on the measurement and identification of corporate financialization. Section 3 accesses the evidence on the causes of corporate financialization and reviews the studies that examine the economic consequences of corporate financialization under different motives. Section 4 discusses some limitations of the extant literature and concludes by highlighting some potential areas of future research.

\section{The Connotation and Measurement of Corporate Financialization}

\subsection{The Connotation of Corporate Financialization}

With the emergence of the economy problem "from real to virtual", some researchers put forward the concept of "economic financialization" (Zhang Chengsi and Zhang Buyu, 2015) [1], which means more and more real economic sector participated in financial investment activities, and more and more percent of profits came from the financial investment activities. The financial behavior of NFCs is the micro-expression of economic financialization. There are differ- 
ent definitions of corporate financialization at home and abroad, and mainly from two aspects: profit accumulation mode and the degree of participation in financial markets. Arrighi (1994), Krippner (2005), Wang Hongjian, Li Wei, Tang Taiqi (2016) argued that corporate financialization means that enterprises were gradually separated from traditional product production and trade activities, and their profits are more dependent on financial investment [3] [4] [5]. That is to say, from the perspective of behavior, corporate financialization is a resource allocation method in which enterprises focus on capital operation, and present a trend of reducing investment in the real economy and increasing investment in financial assets (including commodities with investment properties such as real estate). Some studies have used this kind of financial asset allocation behavior as an alternative to corporate financialization, and studied the causes of corporate financial asset allocation (Hu Yuming, Wang Xueting, Zhang Wei, 2017; Yang Zheng, Liu Fang, Wang Hongjian, 2017; Duchin, R., Gilbert, T., Harford, J., 2017) [6] [7] [8], and found that there was a U-shaped relationship between non-monetary financial assets hold by listed companies and their operating rate of return (Song Jun and Lu Hao, 2015) [9]. From the perspective of results, corporate financialization means that corporate profits are more derived from investment and cap-ital operations of non-production operations, pursuing pure capital appreciation rather than operating profit (Cai Mingrong and Ren Shichi, 2014) [10].

\subsection{Measurement and Identification of Corporate Financialization}

\subsubsection{Measurement and Identification Based on Financial Statements}

According to the definition of corporate financialization, the degree of corporate finance can be measured from two aspects: assets and profits. In general, the higher the financial degree of enterprise is, the higher the proportion of financial assets held in the total as-sets is, and the higher the proportion of the income obtained through financial investment to the total profit is. Therefore, the degree of financialization of assets can be characterized by the ratio of financial assets in the financial statements to total assets, and the degree of financialization of profits can be measured by the ratio of financial income to current operating profit. The formula is as follows:

Degree of Corporate Finance (Assets) $=$ Financial assets/Total assets ${ }^{\star} 100 \%$

Degree of Corporate Finance (Profits) = Financial Profit/Total Profit ${ }^{\star} 100 \%$

Domestic and foreign research is controversial about the definition of numerator (the definitions of financial assets and financial profits). Demir (2009) used cash, short-term investments, and other corporate investment as a measure of corporate financial assets [11]. Xie Jiazhi, Wang Wentao, Jiang Yuan (2014), Liu Wei, Sheng Hongqing, Ma Yan (2014) took investment real estate into the measurement range of corporate financial assets [12] [13]; What's more, shadow banking business has developed rapidly in recent years, but there are no unified 
accounting rules. And entrusted loans, products such as trust loans and bank wealth management are included in other receivables and other liquid assets, which has not been discussed in the past. Song Jun and Lu Xin (2015) used financial framework of Penman and Nissim (2001), and took transactional financial assets, derivative financial assets, net short-term investment, available-for-sale financial assets, held-to-maturity investments, net long-term debt in-vestment; entrusted loans, wealth management products and trust product investment in the details of liquid assets; investment real estate balance; long-term equity investment as financial asset. This research overcame the above three shortcomings. Due to the deviation of the definition of the scope of financial assets, the measurement of financial income also differs. Among them, Stockhammer (2004) takes interest and dividend income into consideration, and Liu Wei, Sheng Hongqing, Ma Yan (2014) defines financial income as the net investment income after deducting the investment income of joint venture and joint venture [13], Song Jun, Lu Hao (2015) includes interest income in financial expenses, financial related parts of investment income, transactional financial assets, transactional finance changes in the fair value of liabilities and investment properties into financial income [9].

In fact, assets and profits are two sides of a coin, reflecting the structure of corporate investment activities. The difference is that the corporate finance measured by assets can objectively reflect the enterprises' subjective will, while the corporate finance measured by profits includes other factors such as market price and risk. When the investor is rational and the market price fluctuations are small, the two measures are relatively consistent. However, if the investor is relatively irrational, or if the financial market price fluctuates greatly and the macroeconomic uncertainty is strong, then the financialization measured by the profits will be interfered by macro factors and market factors, and it cannot reflect the true financial investment willingness correctly.

In addition, considering that cash flow can reflect enterprises' actual earnings more accurately than the book profit, Krippner (2005) uses the cash flow structure to measure corporate financialization [14]. Specifically, he uses the sum of interest income, equity income, and capital gains of NFCs as the cash inflow of financial investment income, and the sum of operating profit and depreciation of fixed assets this year as the cash inflow of productive investment, and then use the ratio of cash inflows from financial investments to cash inflows from productive investments can measure the degree of corporate finance.

\subsubsection{Measurement and Identification Based on the Correlation between Assets and Liabilities}

The above-mentioned financialization measurement directly uses the detailed data of the balance sheet and the income statement, but only applies to the listed company. In order to identify corporate financialization more broadly, Wang Yongqin, Liu Zihan, Li Wei (2015) used the correlation between financial assets and financial liabilities to identify corporate financialization [15]. The theoretical 
basis of this method stems from the financing priority theory (Myers, 1984), that is, when having investment demand, NFCs will give priority to lower-cost internal financing compared with external financing. Specifically, NFCs first reduce financial assets such as cash and cash equivalents, and purchase long-term non-financial assets. When financial assets are converted into long-term non-financial assets, if the investment needs are still not fully satisfied, NFCs will borrow externally funds, therefore, financial liabilities will rise. Financial assets and financial liabilities are changing in the opposite direction. When an enterprise borrows bank funds and engages in financial investment, both financial liabilities and financial assets will rise, and change in the same direction. Therefore, according to the correlation between changes in financial assets and financial liabilities, corporate financialization behavior can be identified. This method is not limited by the integrity of the report data, and can be widely applied to non-listed companies.

\section{Causes and Economic Consequences of Corporate Financialization}

After the outbreak of the subprime mortgage crisis, the issue of corporate financialization has once again attracted widespread attention. In particular, the fact that NFCs in various countries have ventured into the financial sector has spawned research on the factors affecting corporate financialization at home and abroad. Exploring the motivation of corporate financialization and clarifying the different economic consequences under different motives have important guiding and practical significance to prevent corporate financialization risks, thereby preventing excessive virtualization of the economy, and managing the problem of "from real to virtual".

\subsection{The Causes of Corporate Financialization}

Recent years have witnessed a boom in academic research on corporate finance. Reviewing the existing literature abroad, the views of western researchers on the causes of corporate financialization can be divided into three categories: the real economy profit crisis, corporate governance model and shareholder value change, and class exploitation.

1) Profit crisis. Under the increasingly fierce competition and increasingly difficult operations, high returns of financial markets drive enterprises to increase financial investment. Research by scholars such as Orhangazi (2006) and Krippner (2008) argue that the decline in the profit rate of the real economy is the direct cause of the financialization of NFCs. "Facing the declining return on investment, NFCs have to shift capital from the production sector to a financial market" [4] [16]. Demir (2009) believes that there is a causal relationship between the decline in profit margins of traditional industries and economic financialization [17]. When the profit of traditional productive industries enter the downside range, the nature of "maximize the profit" make capital profitabil- 
ity gradually shift to other channels to obtain higher profit margins, which in turn shifts the enterprises' focus from commodity production to financial activities.

2) Changes in corporate governance models and shareholder values. Crotty (2005) believes that under the concept of corporate investment that emphasizes short-term returns, managers are increasingly short-term and financialized. The corporate governance model shifts from focusing on long-term growth to emphasizing short-term capital appreciation, which ultimately leads to NFCs' earnings gradually concentrated in the financial market [18]. Lazonick (2010, 2011) interprets economic financialization from the perspectives of corporate governance model and shareholder value change. He finds that the concept of maximizing shareholder value is an important factor in promoting the financialization of NFCs in the US [19] [20]. These changes in governance methods and concepts make NFCs more dependent on financial markets, and the degree of financialization become deeper.

3) Class exploitation has intensified. The left scholars represented by Hudson (2010) attributed the financialization of NFCs to the expansion of financial capital and the deepening of its plunder and exploitation [21].

Western academic circles have limited ability to generalize and explain the causes of the corporate financialization. It's difficult for the view of the profit crisis to explain that large enterprises that maintain high profit margins also have tendency to financialization. The view of the change of corporate governance can only be supported by the data of listed companies. The view that class exploitation requires a discussion of the difference between financial capital exploitation and other forms of exploitation.

While there is still a lack of persuasive explanation in the western academic circles, domestic scholars' views on the causes of corporate financialization can be roughly summarized as two aspects: capital reserve motives and capital arbitrage motives.

1) Motivation for capital reserve. According to Keyne's (1936) preventive savings theory, financial assets are more liquid than fixed assets. When enterprises face financial difficulties, companies can quickly obtain liquidity by selling financial assets, thereby alleviating corporate financial pressure. On the other hand, when enterprises believe that they will face macroeconomic uncertainties or potential investment opportunities in the future, they also prefer to hold more liquid assets like financial assets to better invest in the real economy. This motivation of financial asset allocation is an act of "preparing for a rainy day", such as mitigating financial distress (Hu Yuming, Wang Xueting, Zhang Wei, 2017) [6], reducing underinvestment (Yang Zheng, Liu Fang, Wang Hongjian, 2017) [7], hedging price risk and exchange rate risk.

2) Capital arbitrage motives. Capital arbitrage motives refer to the tendency that more and more real enterprises are involved in the financial and real estate fields, allocating excessive financial assets, so as to obtain higher returns com- 
paring with the main investment. Since the financial crisis in 2008, China's real economy has been in a state of continuous downturn. The rising labor costs, overcapacity, and cumbersome taxes and other factors have squeezed the profit space of the real economy, and the return on investment in the real economy has been declining. At the same time, the yield of financial investment continues to rise. In the midst of the downturn in the real economy, the government has frequently introduced loose monetary policies. Macroscopic excess liquidity has flowed into the capital market and the real estate market, causing asset price bubbles and real estate price bubbles. The alternating prosperity of the stock market and the real estate market has caused the financial investment yield moreprofits. Faced with the difference in the rate of profits between real economy investment and financial investment, enterprises choose financial investment to maximize profit (Wang Hongjian, 2016; Xie Jiazhi, 2014; Zhang Chengsi and Zhang Buyu, 2016) [5] [12] [22], which is an act of "putting the cart before the horse".

\subsection{Economic Consequences of Corporate Financialization}

Different financial motivations have different economic consequences. Studying the impact of corporate financialization under different motives can help to clarify the mechanism of corporate financialization and propose differentiating measures for different types of financialization. By reviewing the existing literature, we can divide the impact of corporate financialization into two categories: "reservoir" effect and "crowding out" effect.

1) "Reservoir" effect. When the enterprise is financialized due to the motive of capital reserve, this financial asset allocation behavior is conducive to enhancing asset liquidity and alleviating the financing constraints of enterprises (Ding, 2013; Yang Zheng, Liu Fang, Wang Hongjian, 2017) [7] [23], helping enterprises to get rid of Financial distress (Denis and Sibilkov, 2010) [24]. In addition, by holding some financial instruments with diversified risk functions, such as commodity futures and foreign exchange options, enterprises can hedge raw material price fluctuations and exchange rate fluctuations, diversify business risks and improve corporate performance (Demir, 2009) [11], which creates a "reservoir" effect and has a positive impact on the enterprises' future development.

2) "Crowding out" effect. Some researchers have a negative attitude towards corporate financialization from the perspective of the alternative relationship between financial asset allocation and operation asset allocation. According to the resource allocation theory, when the return on financial channel is higher than the operating channel, the interest will drive the managers to change the investment order, the number of financial assets allocation increases, and the fixed asset investment decreases (Tori and Onaran, 2017) [25], and the industrial investment rate correspondingly declines. That's called the "crowding out" effect (Orhangazi, 2008; Davis, 2013) [26] [27]. On the other hand, the financialization of NFCs will increase investment in financial markets and promote corporate 
repurchase of stocks, thereby inhibiting industrial investment (Zhang Chengsi and Zhang Buyu, 2016) [22]. At the same time, due to the higher risks in the financial and investment real estate sectors, financial assets have "risk contagion effect". What's more, affected by risks such as interest rate, exchange rate and policy supervision, the income of financial wealth management products is uncertain and the probability of loss is high. And these risks are likely to be transmitted to the entity. The higher the degree of corporate financialization is, the greater the financial risk of enterprises is (Huang Xianhuan, Wu Qiusheng, Wang Yao, 2018) [28]. What's more, out of profit-seeking motives, enterprises tend to add leverage to cross-industry arbitrage (Wang, H.J., Li, M. and Tang, T., 2016) [5], and excessive financialization has intensified "de-industrialization", weakens manufacturing development, and squeezes out corporate innovation investment (Wang Hongjian, Cao Yuqiang, Yang Qing, Yang Zheng, 2017) [29] prohibits the development of enterprises' future performance (Du Yong, Zhang Huan, Chen Jianying, 2017) [30]. In addition, while financialization increases the overall risk of the enterprises, it also increases the risk of the company's stock price crash risk (Liu Lina, Ma Yamin, 2018; Peng Yuchao, Ni Ruran, Shen Ji, 2018) [31] [32], which will lead to asset price bubbles and systemic financial risks, hindering financial stability and macroeconomic stability.

In summary, different types of corporate finance have different economic effects. The capital reserve motives, which alleviate the financial distress and diversify risks of enterprises, can services entity and contribute to the growth of enterprises and economic development; But corporate finance, which is caused by the decline of the profit rate of the real economy and the asset price bubble, is not conducive to the stability of the financial system and the healthy development of the economy.

\section{Conclusions and Directions for Further Study}

The connotation and characteristics of corporate financialization, as well as the causes and economic consequences of corporate financialization, will have different performances under different situations. The academic community has carried out extensive research and discussion, and has microscopically interpreted the phenomenon of economic financialization from various aspects such as connotation, measurement, causes and economic consequences. From the above, we can see that although the problem of "from real to visual" caused by economic financialization is not conducive to economic development and economic stability, from the micro level, corporate financialization is not without merit. There are pros and cons of corporate financialization. It is necessary to distinguish different causes and propose differentiated governance and control measures. However, there are few existing literatures on financialization involving the countermeasures of financialization, and most of the proposed governance measures are based on macroeconomic perspectives. From the perspective of corporate financialization governance, most of these measures have direction- 
al indications, but it is obviously not enough to implement them at the firm level. Therefore, it is urgent and practical to study further on corporate financialization and pay close attention to the countermeasures of financialization.

In fact, when we distinguish the causes of corporate financialization, we will find that corporates might invest financial assets based on the "reservoir motivation" or "profit-seeking motivation" or even both. Therefore, it is quite difficult to distinguish between the two kinds of corporate financial behavior with different motives and take right countermeasures. Future research on corporate financialization can split a new path by exploring the optimal degree of corporate financialization. Corporates have a positive side in using financial resources to participate in financial activities. We should pay more attention to the excessive corporate financialization. Specifically, corporate financialization should have an optimal level, that is, according to the degree of financialization, it should be divided into insufficient financialization, optimal financialization and excessive financialization, and the macro and micro-level consequences brought by different situations are different. Only excessive financialization will have a more serious negative impact on the entity and the macro economy. Therefore, it is necessary to separate the excessive financialization behavior from the financialization behavior of the entity enterprise in order to better and specifically prevent the negative impact of excessive financialization. We call for further research on this issue to provide a theoretical basis for the supervision of excessive financialization and the solution of the "from real to virtual" problem.

\section{Conflicts of Interest}

The author declares no conflicts of interest regarding the publication of this paper.

\section{References}

[1] Zhang, C. and Zhang, B. (2015) Re-Discussion on Finance and Real Economy: Economic and Financial Perspective. Economic Perspectives, 6, 56-66.

[2] Zou, Y. (2018) The Connotation, Performance and Governance of Economic Financialization: A Literature Review. South China Journal of Economics, 2, 20-30.

[3] Arrighi, G. (1994) The Long Twentieth Century: Money, Power and the Origins of Our Times. Verso Press, London.

[4] Krippner, G.R. (2005) The Financialization of the American Economy. Socio-Economic Review, 3, 73-208. https://doi.org/10.1093/SER/mwi008

[5] Wang, H.J., Li, M. and Tang, T. (2016) The Driving Factors of Cross-Industry Arbitrage and Its Impact on Innovation. China Industrial Economics, 11, 73-89.

[6] Hu, Y., Wang, X. and Zhang, J. (2017) The Motivation for Financial Asset Allocation: Reservoir or Substitution? Economic Research Journal, 1, 181-194.

[7] Yang, Z., Liu, F. and Wang, H.J. (2017) Are Corporate Financial Assets Allocated for Capital Reserve or Speculative Purpose? Management Review, 29, 13-25.

[8] Duchin, R., Gilbert, T., Harford, J., et al. (2017) Precautionary Savings with Risky Assets: When Cash Is Not Cash. The Journal of Finance, 72, 793-852. 
https://doi.org/10.1111/jofi.12490

[9] Song, J. and Lu, Y. (2015) U-shape Relationship between Non-Currency Financial Assets and Operating Profit: Evidence from Financialization of Chinese Listed Non-Financial Corporates. Journal of Financial Research, 6, 111-127.

[10] Cai, M. and Ren, S. (2014) Corporate Financialization: A Literature Review. Finance \& Economics, 7, 41-51.

[11] Demir, F. (2009) Financial Liberalization, Private Investment and Portfolio Choice: Financialization of Real Sectors in Emerging Markets. Journal of Development Economics, 88, 314-324. https://doi.org/10.1016/j.jdeveco.2008.04.002

[12] Xie, J., Wang, W. and Jiang, Y. (2014) Manufacturing Financialization, Government Control and Technology Innovation. Economic Perspectives, 11, 78-88.

[13] Liu, J. Hong, S. and Ma, Y. (2014) The Mechanism of Corporate Participating in Shadow Banking Businesses and Its Model Analysis of Social Welfare Net Loss. Journal of Financial Research, 5, 96-109.

[14] Stockhammer, E. (2004) Financialization and the Slowdown of Accumulation. Cambridge Journal of Economics, 28, 719-741. https://doi.org/10.1093/cje/beh032

[15] Wang, Y., Liu, Z. and Li, C. (2015) Identifying Shadow Banking Activities of Chinese Non-Financial Companies. Management World, 12, 24-40.

[16] Orhangazi, O. (2006) Financialization of the US Economy and Its Effects on Capital Accumulation: A Theoretical and Empirical Investigation. PhD Thesis, University of Massachusetts Amherst, ProQuest Dissertations Publishing.

[17] Demir, F. (2009) Capital Market Imperfections and Financialization of Real Sectors in Emerging Markets: Private Investment and Cash Flow Relationship Revisited. World Development, 37, 953-964. https://doi.org/10.1016/j.worlddev.2008.09.003

[18] Crotty, J. (2005) The Neoliberal Paradox: The Impact of Destructive Product Market Com-Petition and Impatient Finance on Nonfinancial Corporations in the Neoliberal Era. Research Briefs, 35, 77-110.

[19] Lazonick, W. (2010) Innovative Business Models and Varieties of Capitalism: Financialization of the US Corporation. Business History Review, 84, 675-702. https://doi.org/10.1017/S0007680500001987

[20] William, L. (2011) From Innovation to Financialization: How Shareholder Value Ideology Is Destroying the USA Economy. Oxford University Press, Oxford, 3-13.

[21] Hudson, M. (2010) From Marx to Goldman Sachs: The Fictions of Fictitious Capital, and the Financialization of Industry. Critique, 38, 419-444.

[22] Zhang, C. and Zhang, B. (2016) The Falling Real Investment Puzzle: A View from Financialization. Economic Research Journal, 12, 32-46.

[23] Ding, S., Guariglia, A. and Knight, J.B. (2013) Investment and Financing Constraints in China: Does Working Capital Management Make a Difference? Journal of Banking \& Finance, 37, 1490-1507. https://doi.org/10.1016/j.jbankfin.2012.03.025

[24] Denis, D.J. and Sibilkov, V. (2010) Financial Constraints, Investment, and the Value of Cash Holdings. The Review of Financial Studies, 23, 247-269. https://doi.org/10.1093/rfs/hhp031

[25] Tori, D. and Onaran, Ö. (2017) The Effects of Financialization on Investment: Evidence from Firm-Level Data for the UK. Greenwich Political Economy Research Centre.

[26] Orhangazi, Ö. (2008) Financialization and Capital Accumulation in the Non-Financial Corporate Sector: A Theoretical and Empirical Investigation on the US Economy. Cambridge Journal of Economics, 32, 863-886. https://doi.org/10.1093/cje/ben009 
[27] Davis, L. (2013) Financialization and the Nonfinancial Corporation: An Investigation of Firm-Level Investment Behavior in the US 1971-2011. UMASS Amherst Economics Working Papers No. 86, 178-184.

[28] Huang, X., Wu, Q. and Wang, Y. (2018) Financial Asset Allocation and Financial Risks of Enterprises. Journal of Finance and Economics, 44, 100-125.

[29] Wang, H., Cao, Y., Yang, Q. and Yang, Z.H. (2017) Does the Financialization of Non-Financial Enterprises Promote or Inhibit Corporate Innovation. Nankai Business Review, 20, 155-166.

[30] Du, Y., Zhang, H. and Chen, J. (2017) The Impact of Financialization on Future Development of Real Enterprises' Core Business: Promotion or Inhibition. China Industrial Economics, 113-131.

[31] Liu, L. and Ma, Y. (2018) Financialization, Excess Leverage and the Risk of Stock Price Crash of Real Business Entities: A Test Based on the Perspective of Investment of Listed Companies. Journal of Yunnan University of Finance and Economics, 34, 41-55.

[32] Peng, Y., Ni, X. and Shen, J. (2018) The Effect of Transforming the Economy from Substantial to Fictitious on Financial Market Stability: An Analysis on Stock Price Crash Risk. Economic Research Journal, 53, 50-66. 